\title{
Impact of Authentic Leaders on Organization Performance
}

\author{
Shahid Nawaz Khan \\ $\mathrm{PhD}$ Scholar, Faculty of management Sciences, International Islamic University \\ Islamabad, Pakistan \\ Tel: 92-300-979-0119Ｅ-mail: 9790119@gmail.com
}

\begin{abstract}
The purpose of this study is to explore and identify, with the help of literature-review, the new construct of Authenticity, Authentic Leaders, and further its impact on organization performance. As, it is totally a new construct in the leadership domain. It has been introduced/developed in the recent organizational context in order to avoid the un-ethical and un-wanted practices by leaders within the organization. With the help of literature-review, the author has supported the argument that authentic leaders have positive affects on the employees' attitude and behavior which ultimately lead the organization towards the enhanced performance.
\end{abstract}

Keywords: Authenticity, Authentic leaders, Organization performance

\section{Introduction}

Authenticity is the reflection of one's inner values and beliefs in one's behavior, it may be good or bad (Shamir \& Eilam, 2005). Further Goffee \& Jones (2005) said that Authenticity is a quality rather than an individual or personality trait and if you are authentic in your actions then others' perception and belief must develop about your authenticity and others must attribute it to you. Harter (2002) defined authenticity in these words that...

"One acts in accord with the true self, expressing oneself in ways that are consistent with the inner thoughts and feelings".

This study is basically a literature review and efforts have been done in order to investigate, by the help of literature review, that how this new construct "Authenticity" play a vital role in organization performance. As, leaders strongly influence their followers, in an organizational context, to enhance the organization performance. Authentic leaders strongly influence individuals' ability through motivation and stimulation towards better performance. In a result, the individuals perform at the peak of their strength and efforts (Gardner \& Schermerhorn, 2004).

The key purpose of this paper is to research the construct of authenticity, authentic leader, and further its impact on organization's performance. When these leaders, who are the driving force in an organization, become authentic, then to what extent, they will create change/difference in an organization's performance as compare to the organization's prior performance. The objectives of this study would be...

a. To study and explore the construct of authenticity.

b. To link this new construct of "Authenticity" with the construct of "Leadership".

c. To further study and explore that how combinely these two constructs (authenticity and leadership) effectively impact the organization performance.

As this is a new area of research. So for, very little research has been done regarding this domain of "authentic leadership" and a big gap is still there to fill by research. This study focused on the relationship of authentic leadership with the organization performance, in order to understand, the role of authentic leadership in an organizational context. The contribution of this study, to the existing domain of leadership, would be multi-fold. Firstly, it will enhance the employees' perception about authentic leadership and assess the factors that contribute more on changing their perception and opinion. Secondly, it will provide solid reasons, with the help of literature review, that how authentic leaders would motivate and stimulate employees, ultimately this will affect the organization performance. Finally the organization would be in a position to develop authentic leaders to gain competitive advantage in the industry.

\section{Authenticity}

Authenticity means genuine, original, not a fake (Concise Oxford English Dictionary, Eleventh Edition). It has roots in the Greek philosophy. "To thine own self be true" (Harter, 2002). Further Harter (2002) \& Erickson (1995) provide the origin and history of authenticity within the field of philosophy and psychology. The modern 
concept of authenticity has been emerged within the past 80 years (Erickson, 1995a). Authenticity and sincerity have been using interchangeably, while there is difference between the two, as Linonel Trilling (as cited by Avolio \& Gardner, 2005) defines sincerity as....

"Sincerity is congruence between avowal and actual feelings. While, authenticity is the extent to which one is true to the self".

One's sincerity is to represent oneself to others as accurately and honestly. The one is true to others is sincerity, while the one is true to himself is authenticity, one's relationship with one's self (Erickson, 1995 \& Trilling, 1972). Harter (2002) explains the term authenticity in the under mentioned words....

“Authenticity is the combination of one's personal experiences (values, thoughts, emotions and beliefs) and acting in accordance with one true self (expressing what one really think, believe and behaving accordingly). The recognition of oneself and one's act in order to express oneself in the way that is consistent with his inner thoughts and feelings".

Kernis (2003) defines the authenticity as "The unobstructed operations of one's true or core, self in one's daily enterprise". Four components of authenticity were identified by Kernis; awareness, un-biased processing, action and relational. Erickson (1995) \& Heidegger (1962) describe the level of authenticity as people are never entirely authentic or inauthentic but rather they achieve the level of authenticity. A very rare people are authentic by birth and they don't need any learning and guidance to become authentic, for example, (Ghandi \& Nelson Mendela) that fit to the profile of authenticity. Others may have the potential to become authentic but may need help in realizing their potential. They are the most committed people to their goals and there is no need to motivate them towards their goals but it doesn't mean that one cannot become authentic leader but it depends upon his level of commitment to his goal (May et al., 2003).

\section{Authentic Leaders}

Shamir and Eilam (2005) mentioned the characteristics of authentic leaders in the following words.....

“They don't fake their leadership; they don't lead for status, honor, or other personal rewards; they are not copied but are original and they are leaders whose actions are based on values and convictions”.

Authentic leader is confident, hopeful, optimistic, resilient, moral/ethical, future oriented and gives priority to developing associates to be leaders. The authentic leader is true to him/her-self and the exhibited behavior positively transforms or develops associates into leaders themselves (Luthans \& Avolio, 2003). Avolio et al, (2004) defined authentic leaders in these words....

"Authentic leaders are deeply aware of what they think and behave and are perceived by others as being aware of their own and others' values/moral perspectives, knowledge, and strengths; aware of the context in which they operate; and who are confident, hopeful, optimistic, resilient, and of high moral character".

Authentic leaders gain others' loyalty and commitment through trust based relationships rather than by compelling and manipulation. They are aware of their own personality, strengths, and weaknesses and by others' as well. Their behavior towards other individuals is stimulating and motivating as, enable them to learn, grow, and succeed. They always push others towards right directions and success in life and try to enable them to become wiser, freer, and more autonomous (Green-leaf, 1977). Authentic leaders are hopeful, confident, optimistic, resilient, moral/ethical, and future-oriented (Gardner et al., 2005; May et al., 2003). They are focused and concentrated on the development of their followers just like their leaders. They present themselves in front of them as role model to motivate them for becoming future leaders (Avolio \& Gardner, 2005). Authentic leaders care about the interest of all stakeholders as they have the values of benevolence (honesty, responsibility, and loyalty) and universalism (equality, social justice, and broad-mindedness), While, these characteristics are common in other types of leadership, like transformational, charismatic, spiritual, servant, ethical, and so forth. It includes all form of positive leadership but still, it is distinct from other leadership styles (Avolio \& Gardner, 2005; George, 2003; Michie \& Gooty, 2005).

Authentic Leaders are those who lead with purpose, values and integrity. They build enduring organizations, motivates their employees to provide superior customer services and create long term values for shareholders (George, 2003). Through the increased self-awareness, self-regulation and positive modeling, authentic leaders foster the development of authenticity in their followers and in turn the follower's authenticity contributes to their well being and the attainment of sustainable and veritable performance (Gardner et al, 2005). Authentic leaders are not selfish and stereotypes. They are motivated for doing well by the welfare of their subordinates, colleagues, his organization and especially his society. They have moral values and ethics. On the basis of these 
traits, they must not be considered as supernatural human beings and are away from shortcomings and mistakes. They do mistakes but they accept their mistakes as to avoid these mistakes in the future (George, 2003).

\section{Impact of Authentic Leaders on Organization Performance}

Herb Kelleber (As cited by Robert Frost, 2003) founding CEO \& Chairman of the southwest Airlines, who expressed his view about the human nature and people at work, that....

"Isn't a shame that people's mind work furiously until they get to work and then they stopped? Well at Southwest Airlines, they work furiously when they are at work and they work creatively and they work imaginatively."

According to Luthans, (2003)

"Core characteristic of $\mathrm{POB}$ as confidence, hope, optimism and resilience are keys to high performance systems. POB focus on people's strength and avoid their weaknesses”.

Fred Luthans (as cited by Gardner \& Schermerhorn, 2004) defined positive organizational behavior (POB) as...

"The study and application of positively oriented human resource strengths and psychological capabilities that can be measured, developed, and effectively managed for performance and improvement in today's work place".

Positive Organizational Behavior (POB) makes the managers to concentrate on people's strengths rather than weakness (Gardner \& Schermerhorn, 2004) Same as, authenticity concentrates on one's inner thoughts, beliefs and emotions and acting in such a way that reflects one's true self. When the trait of authenticity emerged in some one and that leader become an authentic leader and play a role model for the company's values and company earned this leadership trust through practicing the company's values everyday and thus the authentic leader affect the company performance in positive direction. Authentic leadership for the high performance is not something that cannot be achieved. It is something which is in access of all mangers. It is something realizable and tangible. First selecting, developing and training the talent and then placing the talent into the right job. Only through this process one can achieve excellence at work. Authentic leaders have the following tasks within an organization to make the difference.

\section{a. Confidence (Self-efficacy)}

As firstly, they target the follower's self-efficacy (The state of confidence). According to Alexander Stajkovic \& Luthans, (2004) self-efficacy is strongly linked to work performance as compare to other OB constructs, such as, Job Satisfaction, goal settings, conscientiousness, feed back etc. confident employees always work well under pressure, stress, and face the challenging jobs easily. According to Luthans \& Avolio, (2003) personal confidence helps authentic leaders to know themselves and restrict them to their firm beliefs. Authentic leaders help others to recognize their capabilities.

\section{b. Hope}

The second task of the authentic leaders is to create hope among their followers and it will help employees/followers to set their goals and decide how to reach them and motivate themselves to achieve them. According to Synder, (2002) hope is the combination of two things, agency (the will) and the pathways (the ways) like, goal directing and the plane for reaching to this goal. In some cases, we know the people, they are well aware of their path or even multiple paths to their goals but they lack the willpower to reach over there. Synder, (2002) and his associates are in favor of positive affects of hope on academic, athletic, mental and physical health, while Luthans, (2003) have described the effects of hopeful manager on a work unit, having higher profits, more satisfied employees and lower turnover.

\section{c. Optimism}

The third task of the authentic leaders is to raise optimism. Optimists usually attribute the success to their internal, stable, or global causes such as their own abilities. While, they relate their failure to the external and un-stable causes. They exercise positive emotional states, such as happiness, pride, satisfaction, and enthusiasm. In a result they get success, high achievements in academic, political, professional, mental and physical health as well (Martin Seligman, 1990). They always struggle for continued success in their life and they tend to experience positive emotional states such as pride, happiness, satisfaction and enthusiasm (Gardner $\&$ Shermerhorn, 2004).

\section{d. Resilience}


The fourth task of the authentic leaders is strengthening resilience. The individual facing hardships and difficulties be able to withstand or recover quickly from difficult conditions and emerged with new improved leadership skills. They emerged with more stronger and committed passion rather with un-defeatable passion. Doing the right things even if it creates hardship and difficulties, e.g. Even when the new deodorant was defective, at that time Tom withdrew the product from the market and offered his dissatisfied customers a refund and a personal apology. According to the McGregor, (2005) positive expectations make a significant difference for individual performance. If your expectations will be high, the performance will also be high. In other words, your expectation will enhance your performance. The person with high expectation will outperform as compare to the person with low expectations. (Gardner \& Schermerhorn, 2004).

The solid conceptual and empirical links between authentic leadership and follower's attitude, behaviors and performance outcome have not been developed so far. Some initial work in the development of this broader framework has been done by Avolio et al. (2004), showing that how authentic leaders influence followers attitudes, behaviors and performance. They draw from positive organizational behavior, trust, hope, emotion, identification and identity theories to describe the process by which authentic leaders exert their influence on follower's attitudes and behaviors (Avolio et al. 2004).

\section{Insert figure 1 about here}

This is the proposed model of the authentic leader's contribution towards organization performance. Authentic Leaders focuses on the core characteristics of the followers to enhance the organization performance. It focuses on the follower's strengths and avoids their weaknesses. (Luthans, 2003) In this model, authentic leader increases the core characteristics of the followers e.g. hope, confidence, optimism and resilience and these characteristics further influence the follower's work attitude and this work attitude further affects the follower's behavior for the high performance. Ultimately the follower's performance will affects the organization performance and hence the organizations usually use their authentic leadership as a source for gaining competitive advantage in an industry. Jensen and Luthans (2006) relate the authentic leadership theory to the entrepreneurs especially in the context of smaller and newer organizations and found a positive and significant impact on the employees' attitudes as well as on growth and performance of those business ventures. This factor is very crucial to gain a competitive advantage for the organization, in today's competitive environment. Avolio and Gardner (2005) have showed positive impact of authentic leaders and followers on sustained performance. Gardner et al, (2005) quoted the Warren Buffett, the chairman of Berkshire Hattaway, who sent a short memo to his CEOs....

"In his memo, he indicated that they could lose money, even lots of it. But they cannot afford to lose reputation for honest and high ethical behavior, not a shred of it! He went on to say that it took Berkshire Hattaway 37 years to reach a third place ranking in terms of the most admired companies in the world, and that an inauthentic action on the part of the leaders at Berkshire could result in a catastrophic loss of reputation in less than 37 min!”.

This model shows that authentic leadership is important but not sufficient to achieve the desired goals. The model shows that there is a process linking authentic leadership to follower's attitude and behavior. This model not only shows that how such leaders influence the attitude and behavior of the followers but also show, how independent variables such as hope, trust and positive emotions and optimism can be enhanced.

The second contribution of this proposed model is that it recognizes for the first time the possible role that positive emotions and trust may play in the authentic leadership process. Trust in leadership has been identified as a crucial element in the effectiveness of leaders (Bass, 1990). Trust in leadership is found to be associated with a variety of important organizational outcomes, including belief in information, commitment, organizational citizenship behavior, satisfaction with leaders and intention to stay (Dirks \& Ferrin, 2002). The follower's attitude in this model is commitment, job satisfaction, empowerment and task engagement. The influence of the leadership on commitment and job satisfaction is well documented and little work has been done, that examines the relationship between authentic leadership and employee empowerment.

\section{Conclusion}

This study focused on the new construct of "Authenticity". As Simons (2002) defined this construct very exactly and accurately in the following words which is the complete and easily understandable definition of the construct. "Authenticity is the successful alignment of one's inner values, beliefs, and convictions with one's behavior". Further this construct has been linked with the leadership construct. Leadership which is a driving force in an organization plays a vital role in the success of an organization. This fit between the authenticity and leadership will avoid and reduce un-ethical and un-wanted practices in an organization. Authentic leaders affect the 
followers' behavior and attitude by presenting him/herself as a role model in front of the followers to motivate and stimulate them toward better performance of the organization.

Authentic leaders focus on the followers not on the management practices. They do not tell them the direction rather to develop their confidence (self-efficacy), hope, optimism, and resilience and avoid their weaknesses (Luthans, 2003). As (Gardner \& Schermerhorn, 2004) explained the role of authenticity within the organization. He said that authenticity concentrates on one's inner thoughts, beliefs and emotions and acting in such a way that reflects one's true self. When the trait of authenticity emerged in some one and that leader become an authentic leader and played a role model for the company's values and company earned this leadership trust through practicing the company's values everyday and thus the authentic leader affect the company performance in positive direction. Authentic leadership for the high performance is not something that cannot be achieved. It is something which is in access of all mangers. It is something realizable and tangible. First selecting, developing and training the talent and then placing the talent into the right job. Only through this process one can achieve excellence at work.

\section{Future Directions}

Future research is needed in this connection to gauge/measure the characteristics of authentic leaders. Future research is needed to develop a scale for measuring the authentic leadership in oneself which will authenticate the claim of authentic leadership in organizational context. The follower's outcomes such as extra efforts/discretionary behavior and withdrawal behaviors (turnover, tardiness and absenteeism) should be explored further as to check the significance of authentic leadership impact on follower's attitude and behavior. Further it should be explored and tested in comparison with other leadership styles in context of organization performance.

\section{References}

Avolio, B. J., \& Gardner, W. L. (2005). Authentic leadership development: Getting to the root of positive forms of leadership. The Leadership Quarterly, 16(3).

B Shamir, G Eilam. (2005). "What's your story?" A life-stories approach to authentic leadership development. The Leadership Quarterly, Vol. 21 No. 8

Bass, B. M. (1990). Bass and Stogdill's handbook of leadership: Theory, research, and managerial applications (3rd ed.). New York Free Press.

BJ Avolio, W Zhu, \& W Koh, P. (2004). Transformational leadership and organizational commitment: Mediating role of psychological empowerment and moderating role of structural distance. Journal of Organizational, Vol. 12 No. 6

Boas Shamir, \& Galit Eilam. (2005). What's your story? A life-stories approach to authentic leadership development. The Leadership Quarterly, 16, 395-417

Dirks, K. T., \& Ferrin, D. L. (2002). Trust in leadership: Meta-analytic findings and implications for research and practice. Journal of Applied Psychology, 87, 611-628.

Douglas R. May Adrian Y.L. Chan Timothy D. Hodges Bruce J. Avolio. (2003). Developing the Moral Component of Authentic Leadership. Organizational Dynamics, Vol. 32, No. 3, pp. 247-260

Erickson, R. J. (1995). The importance of authenticity for self and society. Symbolic Interaction, 18(2), 121-144.

George, W. (2003). Authentic leadership: Rediscovering the secrets to creating lasting value. San Francisco Jossey-Bass.

Goffee, R., and Jones, G. (2005). Managing authenticity: The paradox of great leadership. Harvard Business Review, 85, 86-94.

Goldman BM, \& Kernis M. (2002). The role of authenticity in healthy psychological functioning and subjective well-being. Ann Am Psychother Assoc, 5:18-20.

Greenleaf, R.K. (1977). Servant leadership: A Journey into the nature of legitimate power and greatness. Paulist Press, New York, NY. Vol. 17 No. 9

Harter, J. K., Schmidt, F. L., \& Keyes, C. L. M. (2003). Well-being in the workplace and its relationship to business outcomes: A review of the Gallup studies. In C. L. M. Keyes, \& J. Haidt (Eds.), Flourishing: Positive psychology and the life well-lived (pp. 205-224). Washington, DC, American Psychological Association. 
Harter, S. (2002). Authenticity in C. R. Snyder, \& S. Lopez (Eds.), Handbook of positive psychology (pp. 382-394). Oxford UK Oxford University Press.

Heidegger, M. (1962). Being and time, (J. MacQuarrie and E. Robinson, Trans.). London SCM Press. Vol. 14 No. 5

Kernis, M. H. (2003). Toward a conceptualization of optimal self-esteem. Psychological Inquiry, 14, 1-26.

Luthans, F. (2002b). The need for and meaning of positive organizational behavior. Journal of Organizational Behavior, 23, 695-706.

Luthans, F., \& Avolio, B. J. (2003). Authentic leadership: A positive developmental approach. In K. S. Cameron, J. E. Dutton, \& R. E. Quinn (Eds.), Positive organizational scholarship (pp. 241-261). San Francisco, Barrett-Koehler.

Martin Seligman. (1990). Learned Optimism. New York: Pocket Books

May D.R., Chan A, Hodges T, \& Avolio BJ. (2003). Developing the moral component of authentic leadership. Organization Dynamics, 32:247-60.

S Michie, \& J Gooty. (2005). Values, emotions, and authenticity: will the real leader please stand up? The Leadership Quarterly, Vol. 24 No. 3

Shamir, B., \& Eilam, G. (2005). What's your story? A life-stories approach to authentic leadership development. The Leadership Quarterly, Vol. 10 No. 1

Stajkovic, A. D., \& Luthans, F. (1998). Social cognitive theory and self-efficacy: Going beyond traditional motivational and behavioral approaches. Organizational Dynamics, 26, 62-74.

Susan M. Jensen \& Fred Luthans (2006), Entrepreneurs as authentic leaders: impact on employees' attitudes. Leadership \& Organization Development Journal, Vol. 27 No. 8, pp. 646-666

Trilling, L. (1972). Sincerity and authenticity. Cambridge, MA Harvard University Press. Vol. 7 No. 8

TS Gardner, D di Bernardo, D Lorenz, \& JJ Collins. (2003). Inferring Genetic Networks and Identifying Compound Mode of Action via Expression Profiling, Science.

William L. Gardner, Bruce J. Avolio, Fred Luthans, Douglas R. May, \& Fred Walumbwa. (2005). Can you see the real me? A self-based model of authentic leader and follower development. The Leadership Quarterly, 16 (2005) 343-372

William L. Gardner, John R., \& Schermerhorn JR. (2004). Unleashing Individual Potential: Performance Gains through Positive Organizational Behavior and Authentic Leadership. Organizational Dynamics, Vol. 33, No. 3, pp. 270-281

Proposed Model: Impact of Authentic Leadership on Organization Performance

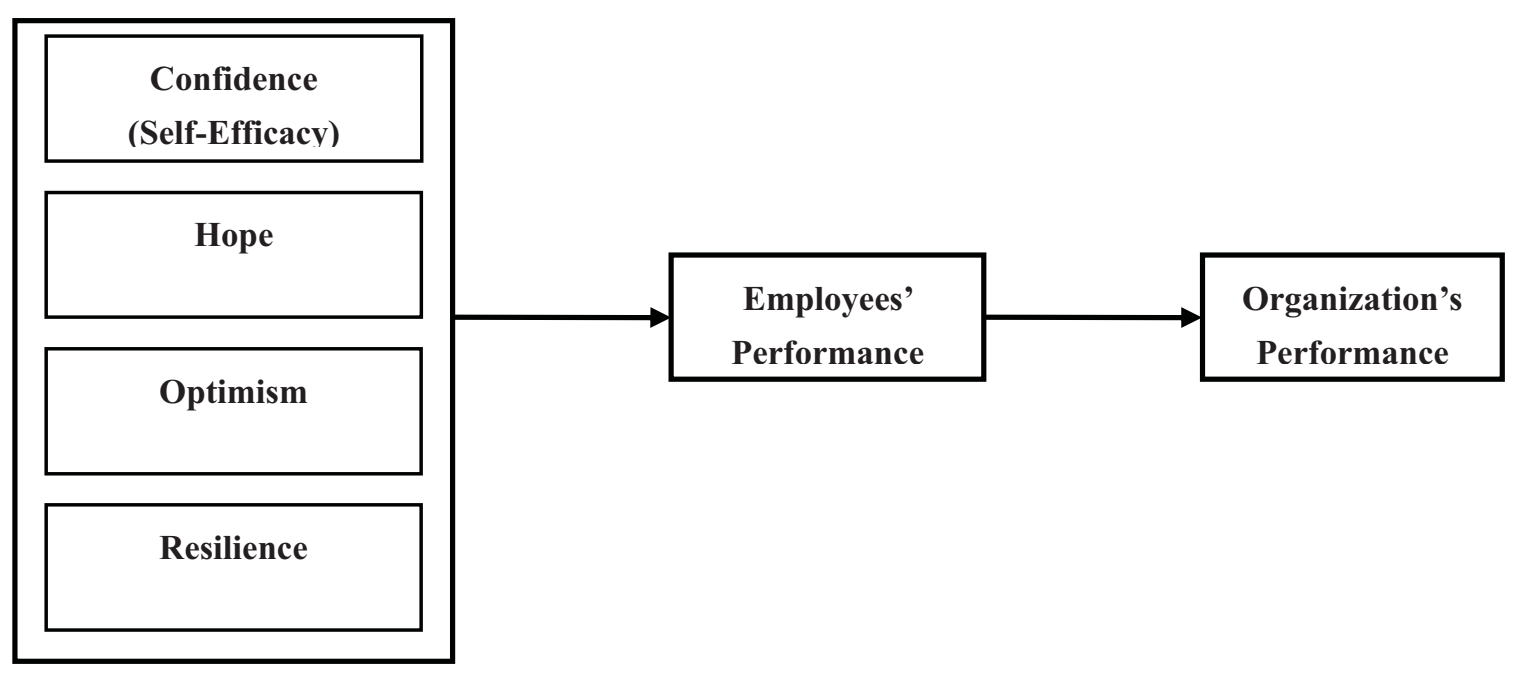

Figure 1. Authentic Leadership 